\title{
Shattered stories: Healing and reconciliation in the South African context
}

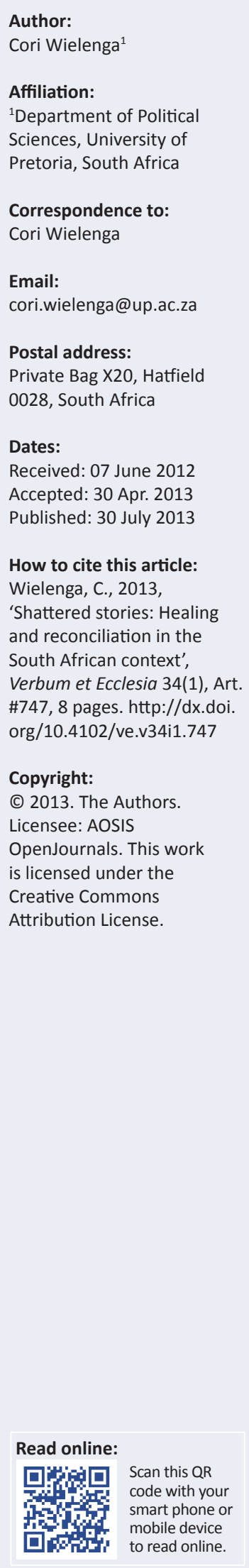

Sharing our stories has been described, by those in the field as well as by popular opinion, as a way to foster healing and reconciliation following violent conflict. This article argues that sharing stories is in itself not necessarily helpful. It is when our stories are shattered by the story of another that meaningful change can begin to take place and new stories can emerge. This idea will be explored in the South African context, with reference to the Truth and Reconciliation Commission as well as current events. It will consider storytelling and reconciliation using John Lederach's four-part model of justice, truth, mercy and peace.

\section{Introduction}

Since the end of apartheid in 1994, reconciliation and healing have had a prominent position in social discourse in South Africa as well as in South African churches. Yet divisions in our society continue to be prevalent, with some suggesting that churches in the country are contributing to the divisions more than that they are healing them. Although the divisions are based on past wounds, the continued inequality, poverty, high levels of violent crime and the uncertain political context perpetuate the divisions. Part of the problem, it is suggested, is that healing and reconciliation have not been sufficiently internalised or explicated in order to be sustainable.

The concept of reconciliation in this article will be understood through John Lederach's four-part model, drawn from Psalm 85:10, which encompasses mercy, truth, justice and peace. Lederach argues that all four elements of this model need to be in balance in order for reconciliation to become a reality. He further suggests that these are most significantly enacted through storytelling. Lederach describes storytelling as a living, interactive process through which new ways of engaging and being with one another are born. Anthony Balcomb takes this further, saying that sharing stories has the biggest impact when we allow our story to be shattered and transformed by that of the other. This includes the shattering of stereotypes, assumptions and ideas that sustain the divisions between us.

Storytelling is not a new concept in the reconciliation process in South Africa; it was a recurring theme during the Truth and Reconciliation Commission (TRC). Although the role of storytelling in the TRC context has been written about extensively (see Bundy 2000; Tutu 2000; Villa-Vicencio 2000), the unique contention of this article is that storytelling in itself is not sufficient; the stories we share need to 'shatter' previously held stories. Furthermore, the potential inherent in the TRC has not been sufficiently translated into meaningful healing and reconciliation in South Africa today. This article will suggest ways in which South Africans and, more specifically, the churches in South Africa can continue to draw from the work that the TRC started.

\section{The role of storytelling in reconciliation}

Human beings are by nature storytellers. We tell stories in order to bring coherence to our lives (Hunt 2010; Rosenwald \& Ochberg 1992:2). In order to make sense of the layers of events that occur in our lives and our interactions with multiple groups of people, we draw everything that happens to us together in a coherent story. These stories are formed in constant dialogue with those events and people and tell us how we perceive the events and people around us and ourselves in relationship to these (Cobely 2001:2).

Not only are our personal life stories embedded in the stories of others, but they are also embedded in the contending narratives of the past and current social, cultural and political narratives (Cobley 2001:2; Hunt 2010). Rosenwald and Ochberg (1992:8) argue that our subjective stories are thus not a romantic fiction separated from the society around us but that, rather, people's stories reflect their interaction with the world and their attempts to create a unique position for themselves within the complexities of multiple layers of reality. 
The stories we have created form a social framework that limits the choices that we see as being possible or moral (Hunt 2010; Rosenwald \& Ochberg 1992:5). There is a trend in narrative research to engage with stories uncritically so as not to impose an 'ideal' onto these stories. A hermeneutical, non-canonical perspective might insist that no one has the right to judge one story as better as or worse than another. However, Rosenwald and Ochberg (1992:6) argue that engaging with our stories critically is imperative for 'emancipation'. Our stories are often developed in struggle with or against other narratives. Every story is then an area of contention or struggle between individuals and the society in which they find themselves. If we see stories as sites of struggle or contention, we could further argue that there are better and worse stories (Hunt 2010; Rosenwald \& Ochberg 1992). Individuals may be able to enlarge the range of their personal story to include more of the stories of others. As individuals become more aware of the influence that their political-cultural conditions have had on their stories, they become able to critique their own story. This critique will most likely lead to a shift in the individual's story and in how they imagine and communicate their position in the society around them (Rosenwald \& Ochberg 1992:8).

Being able to perceive reality in new and more varied ways and being able better to understand the complex dynamic between self and others and between one's own reality and the effect of political and cultural conditions are critical to any process of personal healing and reconciliation with the other. In engaging our stories critically, we shift from the limitations of a narrow story towards the possibilities of change. Sometimes these shifts occur in subtle and almost unperceived ways. At other times, when socio-political circumstances change significantly, these shifts can or perhaps need to occur more consciously. Balcomb argues that, in the context of South Africa where the prevalent stories in society were destructive, we need to consciously choose to have our stories 'shattered' in order to be able to develop new stories. Balcomb suggests that a crisis takes place when our stories are shattered, and the ideas or stereotypes we had are brought into question, and it is this crisis that allows new stories to emerge. He suggests that we need to identify which stories are important to a community or nation, which stories are not important and 'which stories are looking old and haggard and are ready to die' (Balcomb 2000:60).

The new stories give us common ground for understanding one another and acting in new ways that are more inclusive and less destructive. This is particularly the case when we have painted the other as the enemy, the perpetrator or the one who is completely other to ourselves. The process in which our stories are shared and shattered allows for healing.

As with stories, healing is not an isolated activity undertaken by an individual. It is a process which inevitably involves the one who caused the wound as well as the people with whom we are in a relationship and the broader society around us (Staub, Pearlman \& Miller 2003:289). In the South African context, Tutu (2000) argues that we are all wounded, victims as well as perpetrators, and all need to be healed. Healing occurs through, amongst other things, the rebuilding of relationships, which John Lederach (1997:22) suggests is what also leads to reconciliation. He states that people may be living as neighbours and yet remain fixed in endless cycles of hostility, fear and stereotyping (1997:23). His contention is that we do not achieve reconciliation by finding creative ways to avoid one another but by intentionally engaging each other as 'humans-in-relationship' (1997:26). Central to reconciliation is then the restoration of relationships and the recovery of the dignity and humanity of both the victim and perpetrator (Hay 1999:12). This kind of reconciliation leads to healing.

The recent South African Reconciliation Barometer, which is a nation-wide survey measuring reconciliation on an annul basis, reveals that, although race relations in South Africa have improved, interracial interaction and socialisation remains low. The same is most likely to be found in church communities. Sharing our stories takes us beyond interacting superficially towards a deeper engagement with the other so that meaningful healing and reconciliation can take place. The following section will explore reconciliation using Lederach's (1997:28) four-part model of reconciliation, which includes truth, justice, mercy and peace.

\section{Lederach's model of reconciliation}

Lederach argues that, although the four elements of his model may seem contradictory, they cannot operate independently from one another. Truth without justice would be an offence to the victims. Justice without truth might result in historical revisionism which would open the way for new conflicts. Mercy, which is sometimes translated as forgiveness, would be meaningless without acknowledging truth and justice, resulting in impunity for perpetrators. Peace is an essential ingredient for the other elements to become a reality (Lederach 1997:29; Nolte-Schamm 2005:25). In this section, each of these four elements will be explored in terms of storytelling in the South African context, focusing on the contribution of the TRC. The emphasis will be on problematizing these elements of reconciliation, focusing the attention on the complexity of the process.

\section{Truth}

A concern for many people recovering after violent conflict is that the truth of what happened be told. This is a story individuals and a nation repeat to one another in an attempt to bring coherence to past events and to make sense of the present and the future. In the context of the international tribunal following the Rwandan genocide, the possible cathartic effect of speaking the truth is discussed by Adami and Hunt (2005):

For those who remain, for those who lived through the ultimate evil, for those who despaired of seeing the world react, the ICTR becomes a tremendous place to speak. There people can give voice to their suffering, ritualise it, objectify it, reopen the wound to better let it out, let it heal, let it scar over. (p. 112) 
Once the truth is spoken and recorded, it becomes a testimony in the collective memory of a nation and the world, and it is 'fixed in history' (Adami \& Hunt 2005:113).

Yet prolific debate about the nature of the truth that has been spoken has taken place following truth commissions like the TRC. After the TRC hearings, a document of some 500 pages was produced of the story of our past. Bundy (2000:14) argues that the TRC report claimed that the truth was 'a site of contending constructions and perspectives, a realm of subjective, partial truths'. He also reflects on the claims that, through the TRC proceedings, 'we should accept that truth has emerged' (2000:14), implying that a final, factual version of the truth has now been revealed. Bundy critiques the TRC report for favouring conflicting stories over forensic evidence.

Villa-Vicencio (2000:26) argues that the stories that people share are often fragmented and incomplete. He poetically calls for a listening to the incompleteness, the silences, the body language and the complexity of emotions that accompany the telling of stories from the past. The important issue is not that one complete, coherent truth is told, but that new insight is gained into what happened, along with 'an empathetic understanding of how a particular event is viewed by ones adversaries' (2000:27). The crux of the matter is not getting to a so-called ultimate truth but having people on opposing sides begin to see each others' truth with empathy and understanding that will allow for healing to begin to take place.

Yet Staub et al. (2003:290) argue that conflicting views about the past lead to the persistence of blame, mistrust and antagonism. Particularly when groups live together, creating a history that is acceptable to both sides is central to reconciliation. This does not, however, need to be one, contained story. A shared understanding suggests acknowledging and taking into account a diversity of views and perspectives and piecing this together into a version everyone can share. A shared understanding also allows for a dynamic interaction between different groups over time.

Our stories are constantly in flux and being rethought and renegotiated. It is this fluid interaction with our stories, including our stories of the past, which allows reconciliation the space to become a reality. Similarly, Adam and Adam argue that there needs to be room for various versions of the truth rather than a unified, official version. They claim (Adam \& Adam 2000):

Only a pluralist interpretation of history may at best achieve a shared truth, or at worst, reinforce divided memories. History as an ongoing argument is still preferable to the myth-making of official collective memory. (p. 37)

In the case of South Africa, the level of public debate around our past, current political realities, our identity as South Africans and the way forward contribute to developing a flux of dynamically merging stories which create the environment in which reconciliation has the potential to develop.

\section{Justice}

Justice is high on the agenda of the victims of a violent conflict and forms an important part of the kinds of stories a nation develops in the reconciliation process. Justice is often seen to be about victims being compensated for their suffering and perpetrators paying for what they have done. Hartwell (2006), however, describes how, after conflict, all parties tend to see themselves as victims. In South Africa, there are those that survived direct violence under the apartheid regime, there are those we speak of as being previously disadvantaged, and one might argue that anyone who was not White between 1960 and 1994 was, to some degree, a victim. Yet, those who have survived violent crime, those who have lost political and economic power and perhaps many White South Africans living in the post-1994 South Africa may describe themselves as victims. ${ }^{1}$ According to Hartwell, it is natural for victims to want revenge on the perceived perpetrator.

The fact that the democratic government of 1994 did not want revenge and instead implemented a system of political amnesty is very significant. Tutu describes how those who were threatened by the transitions needed to be incorporated in the process in order for them not to become the new victims and to renew violence. Because the participation of those 'threatened by transition' was sufficiently high, the possibility of renewed violence was relatively low (Tutu 2000:22).

Although the route of amnesty seemed at the time the best way for reconciliation and healing to take place in South Africa, in retrospect, many feel it was unhelpful towards the victims of apartheid. Hamber, Nageng and O'Malley (2009:39) describe their study with 20 women who survived political violence during apartheid and testified at the TRC. These women thought that they were testifying in order for the perpetrators to receive punishment. Hamber et al. (2000:39) write that, although the TRC may have had a role to play in the national process of healing and that telling their stories may have been cathartic for some, in the long term, it did not help these victims process their pain and trauma. Although at the time of testifying, those they interviewed felt relieved at the opportunity to be heard by the nation, months afterwards, Hamber et al. (2000:39) found them frustrated and confused by the process. Hamber et al. (2000:40) suggest the possibility that those that testified felt like 'pawns' in a national healing process, where their suffering was used to help the nation but they themselves benefited very little They argue that South Africa made a 'truth for justice trade' which did not benefit the victim (Hamber et al. 2000:41). Hartwell (2006) adds that the TRC 'stifled rage' and the desire for retributive justice. Although she supports the amnesty process as such, her argument is that the rage and desire for revenge that people experienced needed to be acknowledged.

Hamber et al. (2000:42) suggest that financial compensation or a sense that the perpetrators fully understood what they

1.Although the perception of victimhood is clearly problematic here, it is important to acknowledge this perception as it plays a significant role in the willingness of those who perceive themselves as victims to participate in the reconciliation process. 
have done and were prepared to make restitution may have helped in the process of healing where retributive justice was absent. This supports the argument that sharing stories in itself is not always enough if those who are listening to the story have not fully entered into it. In the case of South Africa, it could be argued that a large portion of White South Africans failed to engage the TRC and failed to enter into the stories shared by victims of apartheid and failed to allow their stories to be shattered by the stories of others. This left the storytellers, as described by Hamber et al. (2000:42), feeling resentful and unheard. In contrast to the conclusions of Hamber et al. (2000:42), this article would argue that the need is not for perpetrators to be punished or for financial compensation as much as it is for the perceived perpetrators to engage in victims' stories.

Behind the TRC was the concept of restorative justice, which Consedine (1999:183) describes as embracing a wide range of emotions, including compassion and mercy and 'a world view that says we are all interconnected, and that what we do, be it for good or evil, has an impact on others'. Although this approach was the intention of the TRC and there were numerous examples of meaningful exchanges that took place between victim and perpetrator, there were countless others in which the perpetrator remained without remorse. In addition, on a national level, it has been argued that there has been insufficient remorse on the part of those who benefitted from the apartheid system, which has left many who were disadvantaged by the system resentful. This is the kind of resentment that has the potential to lead to renewed or sustained violence.

Gibson discusses how the TRC amnesty process was in line with a restorative approach to justice, but he argues that a restorative process, particularly in the traditional African context, should include an apology on the part of the perpetrator. In the case of the TRC, it was decided not to demand an apology as this had the danger of being insincere. Gibson argues that the amnesty process was seen as unfair by many South Africans but that:

... when sincere apologies are given, I suspect that South Africans will judge amnesty as more fair to the victims and their families ... Apologies recognized as sincere ameliorate the negative effects of amnesty. (Gibson 2002:543)

A sincere apology would require empathy with victims, entering into their pain and their experience and experiencing remorse for what was done. Based on an extensive survey undertaken in South African in 2000 and 2001, Gibson argues that compensation made little difference to the victims' perceived sense of fairness of the amnesty process. For victims, the crucial factors in their perception of how fair the justice had been seem to be to have one's story heard and to receive a sincere apology (Gibson 2002:554). Because South Africa has chosen the route of amnesty, in order for victims to feel that they have received fair justice, it is imperative that the process of sharing stories and having the stories shattered is taken seriously.

\section{Forgiveness}

After truth and justice, Lederach's model mentions the need for mercy, which he equates with forgiveness. As seriously as we need to take survivors' anger and pain, a retributive approach to justice may not only be damaging but also impractical. In the South African context, Tutu (2000:23) argues that all South Africans had to continue living alongside one another and could not afford to alienate the perpetrators as this had the danger of leading to renewed violence. A retributive approach is also limited in aiding the process of healing and reconciliation. A driving force behind South Africa's choice for a TRC was the desire to live out the precepts of the Constitution in the very way in which the country engaged with justice and reconciliation (Tutu 2000:21). Leaders such as Nelson Mandela and Desmond Tutu wanted to build a country on the principles of forgiveness, amongst others.

Forgiveness played a central role in the TRC proceedings, drawing its meaning from both the Christian understanding of community, koinonia, the kingdom of God and the African concept of ubuntu. Lynn Graybill quotes an example of a testimony at a TRC hearing that embodies this concept:

One of those supporting amnesty was Cynthia Ngeweu, mother of Christopher Piet (one of the Giguletu 7 who was assassinated), who explained her understanding of ubuntu: 'This thing called reconciliation ... if I am understanding it correctly ... if it means the perpetrator, the man who has killed Christopher Piet, if it means he becomes human again, this man. So that I, so that all of us, get our humanity back ... then I agree, then I support it all'. (Graybill 2004:1119)

Forgiveness has remained a difficult element in the reconciliation process with some arguing that it is primarily a religious concept that has no place in secular processes (Jelin 2012). However, forgiveness continues to hold a significant position in transitional justice processes throughout the world with both practitioners and scholars in the field realising its importance for those healing after violent conflict. Nolte-Schamm (2005:16) writes about the centrality of sin, repentance and forgiveness in a Christian understanding of reconciliation. Is it possible, however, to understand the full meaning of forgiveness without including an understanding of sin and repentance? Further still, Tutu and others advocate that the one who was wounded should forgive, even if the perpetrator does not repent or show remorse.

Nolte-Schamm (2005:240) suggests that the possibility of forgiveness without repentance is introduced to us through the New Testament story of the prodigal son. She suggests that, in the paradigm introduced to us by Jesus, the forgiver is able to forgive because they themselves have been forgiven. Forgiveness that is offered as a gift to the perpetrator, regardless of the perpetrator's remorse, takes reconciliation to another level. This would relate to the concept of $u b u n t u$, which suggests that, in order for me to be fully human, I need to recognise the humanity of another. 
In a secular model of forgiveness, Enright (in Hartwell 2006) describes six steps that forgiveness normally follows. In the first few stages, one may find it impossible to forgive, and one may desire revenge whereas, in the final stage, one is able to forgive without needing anything in return. He suggests that the act of forgiveness is not to control the other but to release the other and, arguably, also oneself. This version of forgiveness acknowledges the presence of an injustice whilst releasing the hurt of the act:

While the offended realise they have been treated unfairly, and have no duty to show compassion, they decide to go beyond seeking a 'fair solution', tied to a conditional justice of retribution or reparation, to reach for a compassionate one. This last stage is seen as a final resolution and answer to the offence and it will not be revisited again by either the individual or group involved. (in Hartwell 2006:n.p.)

Following the model of Enright, one could argue that forgiveness does not necessarily emerge from noble intentions such as those described by $u b u n t u$ or the Christian teachings, but it may also emerge from the more pragmatic desire to end cycles of violence or, as Luskin, Thoresen and Harris (2000) describe it, for one's own mental and psychological health and peace (Kulcsár 2006).

In addition to this, as mentioned earlier, perpetrators also need to forgive themselves and their fellow perpetrators. Tutu held that all South Africans had been hurt by apartheid and needed to be forgiven and healed, regardless of whether they were perpetrators or victims. 'All of us South Africans are less whole than we would have been without apartheid' (Tutu 2000:154). He called on people to forgive regardless of whether remorse was shown in the belief that forgiveness is pivotal if a nation is not to fall into an endless cycle of revenge.

Although this led to some moving and transforming experiences during the TRC hearings and in other contexts in South Africa since then, the critique has been that those responsible for political crimes did not take full responsibility for their actions and that the structural violence meted out by the apartheid system was not sufficiently acknowledged (Ntsimane 2000). Tutu's ideal creates a powerful alternative to revenge cycles, but some might argue that it lets perpetrators off the hook. Sharing stories to the point where our stories are shattered demands the engagement of both the storyteller and the listener. The kind of engagement that demands of the listeners that they be participants procures a greater likelihood of listeners taking responsibility for their part in the story.

\section{Peace}

The last element in Lederach's model is peace. Galtung, in his seminal work on peace, distinguishes between negative peace, which he describes as the absence of war, and positive peace, which is the 'integration of human society'. He further argues that peace is not only the absence of direct violence but also of indirect violence, which includes structural violence (Galtung 1964:2). Structural violence creates the conditions in which direct violence can take place, and thus Galtung argued that peace efforts need to focus on structural violence to ensure sustainable change in a society (1969:171).

One significant point of criticism against the TRC is that it did not deal with the structural violence of the apartheid system that allowed direct violence to occur (Ntsimane 2000). However, the church in South Africa did respond to this structural violence through the KAIROS document of 1985 . The 156 signatories, from more than 20 denominations, condemned the tenets of apartheid that allowed a government to oppress the majority of its citizens. The theological justification of apartheid were 'laid bare and exposed as untenable because of the enormity of the injustice' (Hrynkow, Byrne \& Hendzel 2010). The document called on the church to bring about change and suggested that reflecting on a just society should become a central part of worship. Significantly, the KAIROS document declared itself 'an open ended document that could never be said to be final' (1985).

At the ninth assembly of the World Council of Churches, the International Ecumenical Peace Convocation 2011 was signed. Enns (2011) describes this Peace Convocation as one in a series of important milestones in the long succession of ecumenical activity and thinking on the possibilities of non-violent conflict resolution and commitment to justice for all. He writes that the Convocation was an opportunity for confession and repentance for all that had not yet been achieved, 'where churches have remained implicated in violence and entrenched behind "thick church walls"' (Enns 2011:44). He elaborates on these 'thick church walls' describing this as follows:

all situations where churches are timid and inward looking and choose to be isolated from the real challenges facing society, supposedly for the sake of self-preservation or maintaining their privileges as churches or ecumenical organisations. (p. 45)

It has been argued that many of the challenges we face in South Africa today are as a result of not having dealt with the structural violence that underpinned the apartheid system (Ntsimane 2000). Inequality which leads to poverty, unemployment and violent crime remains part of the South African reality. The KAIROS document poses a challenge to the church today to condemn the structural violence that continues in society and take action to bring about change and to make reflections on a just society an integral part of worship. One practical way that this may happen is through shattering the stories that allow structural violence to continue. The following section will consider some ways in which stories may be shattered in the South African context, followed by a discussion of how they may be shattered in the church.

\section{Shattering stories in South Africa}

This article has referred repeatedly to the TRC process. The most powerful impact of the TRC would perhaps be exactly the advantages that storytelling offers to reconciliation 
processes, namely, to be challenged and changed through hearing the stories of others. Nolte-Schamm describes the experience of the well-known South African journalist, Antjie Krog:

... through being exposed to, and allowing herself to be challenged by, the collective memories of groups other than her own, was able to start critiquing her own story; her own story was 'stretched'. (Nolte-Schamm 2000:41)

Through sharing stories, our own story is challenged so that new stories can begin to emerge.

One important way that this can happen is through what the director of a non-governmental organisation in Rwanda, Michel Kayitaba, has described. He spoke of the word for forgiveness in the Rwandan language, kubabarira, as coming from the word urira, which means 'to cry'. Kayitaba encourages perpetrators and victims, or all those hurt by the events of the past, to cry together for their shared loss of humanity. We should be crying together for the way in which we have all been manipulated by politics and power play, crying together for the way in which stereotypes have divided a nation, crying together for those affected by violent crime and crying for the perpetrators of these crimes. Beyond debate in the public sphere, there is a need to share pain and wounds together. Part of the process towards crying together may be being angry at one another and expressing the bitterness and grief in one's story.

In sharing and engaging in stories, human dignity is restored (Hay 1999:12). As stories are shared, heard and acknowledged as legitimate, people enter into a process of being restored as human beings in valid relationships with one another. Villa-Vicencio (1997:105) writes that storytelling assists us in the process of accepting and celebrating our differences, enables us to understand each other well enough to co-exist and builds a common nation 'in diversity and difference'. How the past and the nature of the conflict are perceived and remembered has a significant effect on the likelihood of conflicting parties reconciling. It is necessary for everyone's stories to be heard and told and not for only one set of stories to be heard. As long as our stories are dismissed as being false versions of reality, or perhaps unimportant because they are focused on the past or, alternatively, because we are from a minority group, we feel unacknowledged as human being in relationship to others and become alienated from others.

How do we then share these stories when, as the recent South African Reconciliation Barometer indicates, South Africans of different races struggle to interact socially? There are a number of established organisations that create opportunities for sharing stories. The Institute for the Healing of Memories, started by Father Michael Lapsley in 1998, holds workshops to facilitate interracial reconciliation and healing (Hamber \& Wilson 2002:137). African Enterprise has held Bridge Building Encounters since the late 1990s in which participants from a variety of backgrounds are challenged to reconsider their stereotypes, misconceptions and concerns. The Alternatives to Violence Program initiated by the Quaker Peace Centre in Cape Town allows people from different backgrounds to learn to resolve their conflicts non-violently. These programs are examples of the kinds of spaces that can be created to facilitate the sharing of stories.

A storytelling approach to reconciliation suggests that, in the sharing of our stories, we begin to renegotiate the boundaries between groups. As we begin to share our stories, we shift our understandings of self and other, thereby shifting the boundaries between 'them' and 'us' until, perhaps, we can come to a point of a shared identity beyond the boundary. Sharing our stories is meaningful in fostering healing and reconciliation and breaking down the violence that lies deeply embedded in our society.

\section{Shattering stories in the Church context}

In an article entitled 'The social meaning of reconciliation', Miroslav Volf (1999:8) writes a critique of the role that churches have so often played in violent conflict. He writes that, although churches are the presumed instruments of peace, in the face of violent conflict, they are instead often impotent, at best, or perpetrators of violence, at worst. He argues that talking about reconciliation from the pulpit is not enough but that the social meaning of reconciliation needs to become a reality in church practice.

Although churches may embrace the concept of reconciliation in an abstract sense at the same time, they may be perpetuating the very stories that sustain divisions, stereotyping and othering in society. In the South African context, the most obvious way in which these divisions are perpetuated is in those cases where churches remain homogenous in terms of race and class. However, there are less obvious ways in which divisive stories are perpetuated, both in homogenous churches and those that are more diverse.

In churches whose congregations reflect a single race and/ or class group, hearing the stories of others is a challenging task. Yet even in this circumstance, openness can be created for the congregation to become more receptive to the stories of others. For such churches to merely engage with the other as either the giver or the recipient of charitable actions, as is often the case between a wealthy White congregation and a disadvantaged Black congregation, is not sufficient for a shattering of stories to take place. Creating this openness begins with an awareness of one's own story and how it has been shaped by our socio-political conditions, as described by Rosenwald and Ochberg (1992:4). It further requires creating intentional opportunities to hear the stories of others. Storytelling events, where members of a congregation have the opportunity to share their own stories with one another and the opportunity to share stories with those outside of the community, have the potential to be transformational.

In personal conversations about reconciliation and violence in South Africa with White communities, anger has been 
expressed that the stories of those previously disadvantaged are being told over and over whilst their own stories of trauma as a result of crime are ignored. Alongside this are the stories of past suffering, including what happened during the border war and in the military context. South Africans who feel that their story is not being heard or is not taken seriously in the broader national narrative may be less willing to engage with others' stories of the past. Sharing stories involves not only listening to the other but having an opportunity to share one's own stories as well. Healing and reconciliation take place in the mutuality of the sharing, and such sharing has the potential of bringing recognition of the sameness of the other that shatters long-held assumptions.

The danger in multiracial congregations is the belief that by merely being in church together, reconciliation is taking place. Creating opportunities for socialising and interacting does contribute to a certain degree of familiarity, but what may remain is the feeling that the other is still 'other'. There may even be deeply held resentments based on assumptions about the other that would be found to be untrue were those assumptions challenged.

Drawing from the work of organisations such as the Institute for the Healing of Memories and African Enterprise, a wide scope of possibilities is available for churches that are willing to engage in sharing stories intentionally. Using the models provided by these organisations, multiracial congregations can plan to have story-sharing encounters around a meal or a braai fire at the church on a regular basis. Congregations that have outreaches to impoverished communities can take the time to hear stories from the community and share their own stories which have the potential of transforming the encounter from the problematic one of the 'rich' congregation patronising the poorer one to a mutual sharing and learning experience.

Sharing and shattering stories have a potentially powerful role to play in reconciliation in the churches. Churches in South Africa are in danger of perpetuating stereotypes, assumptions and divisions in our society through allowing particular stories to continue circulating unchallenged. Although many churches have made significant attempts towards reconciliation during apartheid, and even more so since 1994, Volf's warning that churches have a tendency to become perpetrators rather than peacemakers has the danger of becoming a reality in the South African context in terms of the stories that are shared.

\section{Conclusion}

This article contended for sharing our stories as a response to violence in South Africa and argued further that old and stunting stories need to be shattered in order for new, shared stories to emerge. Examples were drawn from the TRC in order to reflect on the role stories play in reconciliation. Using Lederach's four-part model of reconciliation, the complexity of the role of stories was explored in terms of truth, justice, mercy and peace.
It was argued that the church has a pivotal role to play in transforming society and creating communities of peace. One way of doing this is through storytelling, becoming aware of the socio-political context in which one's own story has emerged and intentionally creating opportunities where one's story can be shattered by the stories of others. As we enter into the story of another, relationships have the potential to be restored and new stories begin to emerge.

\section{Acknowledgements}

The author would like to thank the anonymous reviewers who contributed to this article through their very helpful suggestions, advice and recommendations.

\section{Competing interests}

The author declares that she has no financial or personal relationship(s) that may have inappropriately influenced her in writing this article.

\section{References}

Adam, H. \& Adam, K., 2000, 'The politics of memory in divided society', in W. James \& L. van der Vijver (eds.), After the TRC, pp. 32-44, The Rustica Press, Cape Town.

Adami, T. \& Hunt, M., 2005, 'Genocidal archives: The African context - genocide in 'Rwanda', Journal of he Society of Archivists 26(1), 105-121. http://dx.doi. org/10.1080/00039810500047557

Balcomb, A., 2000, 'The power of narrative: Constituting reality through storytelling', in P. Denis (ed.), Orality, memory and the past: Listening to the voices of Black Clergy under Colonialism and Apartheid, pp. 51-61, Cluster Publications, Pietermaritzburg.

Bundy, C., 2000, 'The beast of the past: History and the TRC' in W. James \& L. van der Vijver (eds.), After the TRC, pp. 9-20, The Rustica Press, Cape Town.

Cobley, P., 2001, Narrative, Routledge, London.

Consedine, J., 1999, Restorative justice: Healing the effects of crime, Ploghshares Publications, Christchurch.

Enns, F., 2011, The International Ecumenical Peace Convocation: Towards an Ecumenical Theology of Just Peace?, Blackwell Publishing Ltd, Oxford.

Galtung, J., 1964, 'An editorial', Journal of Peace Research 1(1), 1-4. http://dx.doi. org/10.1177/002234336400100101

Galtung, J., 1969, 'Violence, peace and peace research', Journal of Peace Research 6(3), 167-191. http://dx.doi.org/10.1177/002234336900600301

Gibson, J., 2002, 'Truth, justice and reconciliation: Judging the fairness of amnesty in South Africa', American Journal of Political Science 46(3), 540-556. http://dx.doi. org $/ 10.2307 / 3088398$

Graybill, L.S., 2004, 'Pardon, punishment, and amnesia', Third World Quarterly 25(6), 1117-1130. http://dx.doi.org/10.1080/0143659042000256922

Hamber, B., Nageng, D. \& O’Malley, G., 2000, “'Telling it like it is...”: Understanding the Truth and Reconciliation Commission from the perspective of survivors', Psychology in Society 26, 18-42.

Hamber, B. \& Wilson, R.A., 2002, 'Symbolic closure through memory, reparation and revenge in post-conflict societies', Journal of Human Rights 1(1), 35-53. http:// dx.doi.org/10.1080/14754830110111553

Hartwell, M.B., 2006, 'Perceptions of justice, identity, and political processes of forgiveness and revenge in early post-conflict transitions', Journal of Humanitarian Assistance, viewed 25 May 2010, from http://www.jha.ac/articles/a187.pdf

Hay, M., 1999, Ukubuyisana: Reconciliation in South Africa, Cluster Publications, Pietermaritzburg.

Hunt, N., 2010, War, memory and trauma, Cambridge University Press, Cambridge.

Hrynkow, C., Byrne, S. \& Hendzel, M., 2010, 'Ecotheology and inculturation: Implications for theory and practice in peace and conflict studies', Peace and Change 35(2), 295-327. http://dx.doi.org/10.1111/j.1468-0130.2009.00629.x

Jelin, F., 2012, Social and political struggles for memories: Recent histories in South America and beyond, opening keynote speech as the SIT Symposium on Conflict, Memory and Reconciliation, Kigali, Rwanda, 10-12 January 2012.

KAIROS Document, Challenge to the Church, rev. 2nd edn., 1985, Skotaville Publishers, Braamfontein.

Kulcsár, A., 2006, 'Forgiveness and mental health', Theologia Catholica Latina 1(1), 93-102.

Lederach, J.P., 1997, Building peace, United Institute of Peace, Washington, DC. 
Luskin, F., Thoresen, C.E. \& Harris, A.H., 2000, 'Forgiveness and health: An unanswered question', in M.E. McCullough, K.I. Pargament \& C.E. Thoresen (eds.), Forgiveness: question', in M.E. McCullough, K.I. Pargament \& C.E. Thoresen (eds.),
Theory, research, and practice, pp. 254-280, Guilford Press, New York.

Nolte-Schamm, C., 2005, A comparison between Christian and African Traditional paradigms of reconciliation and how they could dialogue for the benefit of South African society, unpublished DTh dissertation, Department of Theology, University of KwaZulu-Natal, Pietermaritzburg.

Ntsimane, R., 2000, 'A mirage called forgiveness: A critique of the Truth and Reconciliation Commission', in P. Denis (ed.), Orality, memory and the past: Listening to the voices of black clergy under colonialism and apartheid, pp. 20-33, Cluster Publications, Pietermaritzburg.

Rosenwald, G. \& Ochberg, R.L., 1992, Storied lives, Yale University Press, New Haven.
Staub, E., Pearlman, L.A. \& Miller, V., 2003, 'Healing the roots of genocide in Rwanda', Peace Review 15(3), 287-294. http://dx.doi.org/10.1080/ 1040265032000130878

Tutu, D., 2000, No future without forgiveness, Random House, New York.

Villa-Vicencio, C., 1997, 'Telling one another stories: Toward a theology of reconciliation', in G. Baum \& H. Wells (eds.), The reconciliation of peoples, pp. 30-41, Orbis Books, New York.

Villa-Vicencio, C., 2000, 'The limitations of academic history: The quest for truth demands both more and less', in W. James \& L. van der Vijver (eds.), After the TRC, pp. 21-31, The Rustica Press, Cape Town.

Volf, M., 2006, The end of memory: Remembering rightly in a violent world, Grand Rapids, Eerdmans. 